\title{
Letter
}

\section{If we want a whole Earth, Nature Needs Half: a response to Büscher et al.}

Büscher et al.'s (2016) recent article 'Half-Earth or Whole Earth? Radical ideas for conservation, and their implications' raises some important issues for conservation, but it paints a misleading picture of the Nature Needs Half movement. Nature Needs Half expresses three main tenets: (1) habitat loss and degradation are the leading causes of biodiversity loss, (2) current protected areas are not extensive enough to stem further loss of biodiversity, and (3) it is morally wrong for our species to drive other species to extinction (Wilson, 2016). Conservation biologists agree that to maintain viable populations of most of Earth's remaining species, we will need to protect c. $50 \%$ of landscapes and seascapes from intensive human economic use (Noss \& Cooperrider, 1994; Locke, 2014). This bold goal is necessary if we hope to bring our societies' massive displacement of other species to an end.

Necessary, but not sufficient. Büscher et al. correctly note that setting aside more habitat for other species will not preserve them if we continue to misbehave in more developed areas: over-consuming and generating excessive pollution, for example. It is all one Earth, after all, and protected areas are often degraded by external actions. We also agree with Büscher et al. that any significant changes in land use, including Nature Needs Half, must be made with due consideration for the rights and interests of the world's poor and indigenous peoples (Kopnina, 2016). This accords with a consensus among conservationists that local communities should be actively involved in conservation efforts.

However, intraspecies justice-justice for peopleshould not come at the expense of interspecies justice: the very existence of other species. Nature Needs Half proponents envision a world where all species can flourish (Goodall, 2015). This will require setting aside sufficient habitat for other species while living justly and prudently on the remainder. Supporters of Nature Needs Half agree with Büscher et al. on the need to challenge the neoliberal growth economy (Crist, 2014); our proposal does precisely that, by protecting many more areas from its ravenous demands for natural resources. Creating such a mutually flourishing world will also require limiting human numbers, another sharp challenge to the endless growth economy (and a subject ignored by Büscher et al.).

The scientific consensus is clear: humanity is on a trajectory to cause a mass extinction unrivalled in the last 65 million years of life on Earth (Secretariat of the Convention on Biological Diversity, 2014). This calamity can be avoided only by setting aside far more of Earth's land and seas for conservation, and by developing ecologically sustainable societies. We believe doing so is a moral imperative (Cafaro \& Primack, 2014). We owe it to the many magnificent and unique forms of life that remain, who we have no right to exterminate, and we owe it to future human generations, who will be grateful to inherit a lively, diverse, resilient and beautiful biosphere.

Philip CAFARo School of Global Environmental Sustainability, Colorado State University, 108 Johnson Hall, Fort Collins, CO 80523 USA. E-mail philip.cafaro@colostate.edu

Tом BUtLeR Foundation for Deep Ecology, San Francisco, USA EILEEN CRIST Department of Science and Technology in Society, Virginia Tech, Blacksburg, USA

PAUL CRYer Applied Ecology Unit, African Conservation Trust, KwaZulu-Natal, South Africa

ERIC DINERSTEIN RESOLVE, Washington, DC, USA

HeLEN KopNINA Department of Cultural Anthropology and Development Sociology, Universiteit Leiden, Netherlands

REED Noss Department of Biology, University of Central Florida, Orlando, USA

JоHN PICCOLO Institution for Environmental and Life Sciences, Karlstads Universitet, Sweden

BRON TAYLOR College of Liberal Arts and Sciences, University of Florida, Gainesville, USA

CARLY VynNe Nature Needs Half Network, Washington, DC, USA

HAYDN WASHINGTON Interdisciplinary Environmental Studies, University of New South Wales, Kensington, Australia

\section{References}

Buscher, B., Fletcher, R., Brockington, D., Sandbrook, C., Adams, W., CAmpbell, L. et al. (2016) Half-Earth or Whole Earth? Radical ideas for conservation, and their implications. Oryx, http:// dx.doi.org/10.1017/So030605316001228.

CAFARO, P. \& PrimaCK, R. (2014) Species extinction is a great moral wrong. Biological Conservation, 170, 1-2.

Crist, E. (2014) Choosing a planet of life. In Overdevelopment, Overpopulation, Overshoot (ed. T. Butler), pp. 294-301. Foundation for Deep Ecology/Goff Books, Novato, USA.

Goodall, J. (2015) Caring for people and valuing forests in Africa. In Protecting the Wild: Parks and Wilderness, the Foundation for Conservation (eds G. Wuerthner, E. Crist \& T. Butler), pp. 21-26. Island Press, London, UK.

Kopnina, H. (2016) Half the earth for people (or more)? Addressing ethical questions in conservation. Biological Conservation, 203, 176-185.

Lоске, H. (2014) Nature needs half: a necessary and hopeful new agenda for protected areas in North America and around the world. The George Wright Forum, 31, 359-371.

Noss, R. \& Cooperrider, A. (1994) Saving Nature's Legacy: Protecting and Restoring Biodiversity. Island Press, Washington, DC, USA.

Secretariat of the Convention on Biological Diversity (2014) Global Biodiversity Outlook 4. Montréal, Canada.

Wilson, E.O. (2016) Half-Earth. Our Planet's Fight for Life. Liveright Publishing, London, UK. 